\title{
Towards Sustainable Development in Education: Implementing a VET System for In-Service Teachers in Albania
}

\author{
María-José Vieira (D), Camino Ferreira *, Agustín Rodríguez-Esteban * (D) and Javier Vidal \\ Department of Psychology, Sociology and Philosophy, University of León, 24071 León, Spain; \\ maria.vieira@unileon.es (M.-J.V.); javier.vidal@unileon.es (J.V.) \\ * Correspondence: camino.ferreira@unileon.es (C.F.); arode@unileon.es (A.R.-E.)
}

Citation: Vieira, M.-J.; Ferreira, C.; Rodríguez-Esteban, A.; Vidal, J.

Towards Sustainable Development in Education: Implementing a VET System for In-Service Teachers in Albania. Sustainability 2021, 13, 8739. https://doi.org/10.3390/su13168739

Academic Editors: David Molero and Inmaculada García-Martínez

Received: 1 July 2021

Accepted: 2 August 2021

Published: 5 August 2021

Publisher's Note: MDPI stays neutral with regard to jurisdictional claims in published maps and institutional affiliations.

Copyright: (C) 2021 by the authors Licensee MDPI, Basel, Switzerland. This article is an open access article distributed under the terms and conditions of the Creative Commons Attribution (CC BY) license (https:/ / creativecommons.org/licenses/by/ $4.0 /)$.

\begin{abstract}
The Albanian Strategy of Pre-University Education (2014-2020) stated the need to raise the competencies of in-service teachers in the non-university sector by asking Albanian universities to provide Vocational Education and Training (VET). The Erasmus+ project, entitled "Developing Teacher Competences for a Comprehensive VET System in Albania" (TEAVET, 2017-2020), contributed to the design and implementation of a VET system based on the previous literature of five dimensions: context, content, commitment, capacity and clients. The aim of this study was to assess the VET system for in-service teachers in Albania under these dimensions and identify key elements for sustainability. Through a mixed methods approach that merged quantitative and qualitative data (questionnaires and assessment reports), information was retrieved from the directors of lifelong learning (LLL) centres at eight Albanian universities, the Albanian Ministry of Education, Sports and Youth, in-service teachers $(\mathrm{n}=1775$, response rate $76 \%$ ), teacher educators from universities $(\mathrm{n}=44$, response rate $82 \%$ ) and an external expert. Results show that the VET system for in-service teachers in Albania accomplishes these five dimensions. The main elements for sustainability are that the VET system addresses specific Albanian educational priorities, the Ministry is highly committed and that universities have been empowered as LLL providers within their third mission strategy.
\end{abstract}

Keywords: Albania; lifelong learning; vocational education and training; teacher education

\section{Introduction}

One of the United Nations' Sustainable Development Goals (or SDGs) to be reached by 2030 is quality education, to ensure inclusive and equitable quality education and promote lifelong learning opportunities for all [1]. SDGs apply to all citizens in order to reach a better future for everyone. This study analyses the success factors of the TEAVET project, which has contributed to SDGs through the establishment of a lifelong learning system for in-service teachers in Albania, promoted by the Ministry of Education, Sports and Youth (MoESY) and building on the capacity of Albanian universities.

\subsection{Lifelong Learning for In-Service Teachers: Contributing to Sustainable Development}

Quality education is a fundamental pillar to guarantee social cohesion and sustainable growth. Ensuring quality education implies the continuous modernisation of educational systems [2,3], which includes improvements in the training of in-service teachers [4]. Inservice teacher training brings together a set of activities and educational practices in which teachers engage to expand their knowledge and capacities to be applied during their careers [5]. To accomplish this, teachers need to commit to training, but the improvement of the quality of teaching also requires institutional commitment, both on the part of the governments and on the part of international organisations [1,6,7]. In this sense, the European Commission through the New Skills Agenda for Europe [2] supports Member States in modernising their lifelong learning (LLL) policies and to strengthen human capital, employability and competitiveness [8]. In this framework, the European Commission 
specifically encourages policies that address in-service training for teachers to continue their professional development [9-11].

Establishing a successful and sustainable teacher professional development model at local, regional or national levels is not an easy task; it should be developed from a systemic approach based on real demands, capacities and professional needs [12], rather than a set of isolated activities, as is the case in several regions [13]. Thus, compared to the idea of consumption, which is characteristic of a society based on production, LLL is linked to the idea of sustainability since it leads to updating training as a sustainable process [14-16].

In the designing of a professional development system for in-service teachers that aspires to be sustainable, several specific elements should be considered. Firstly, as previously stated, real teacher training needs and demands must be identified. Secondly, the identification of in-service teacher training needs is essential to define the profile of suitable teacher educators [6], those professionals who actively facilitate the formal and informal learning of in-service teachers. The European Commission has also specifically focused on the support for the training of teacher educators, warning that in most European countries there are no precise policies to define what profile is required for them [17]. The profile of teacher educators should be based on previously identified in-service teacher needs, so that they can be selected and trained according to the criteria of relevant competencies, together with the necessary practical experience. Despite the complexity that this entails [18], it is necessary to develop reference frameworks for teacher educators, drawn up from a constant dialogue between theory, practice and research, which include the functions that in-service teachers perform and the competences that must be required of them [19]. Thirdly, the profile of teacher educators is related to one key element in the design of a professional development system: The identification of the agent responsible for training in-service teachers. Across countries, there is a diversity of agents that offer training to in-service teachers [20]. Among them, universities are increasingly being placed as key agents for LLL [21] as a core dimension of their Third Mission, that is, their commitment with society at large in order to extend their knowledge outside the university setting [22-24].

These three specific elements, which can be summarised in the capacity of universities as agents that can provide teacher educators based on teacher training needs, are aligned with theoretical frameworks on how to implement VET systems for LLL. One of the most comprehensive frameworks is the 5Cs model developed by Najam [25]; this describes the implementation processes of VET systems through five determinant dimensions: The context of the policy itself, which refers to what is intended to be done (objectives) and the way in which it is intended to achieve the objectives (methods); the nature of the institutional context, the institutional procedures that allow the development of the system; the commitment of those responsible for carrying out the implementation at different levels; the administrative capacity to develop the changes that must be implemented and the support of clients (employers, intermediaries and educators), and the strategies they use to strengthen or divert their implementation. A recent review on how to implement successful VET systems conducted by Caves, Baumann and Renold [26] confirms the influence of the following key success factors for each of these five interrelated dimensions: (1) context (context fit), (2) content (strategy and accountability), (3) commitment (political will and cooperation), (4) capacity (personnel, finances and research) and (5) clients (employers, intermediaries and educators). These dimensions need to be evaluated, not only because evaluation facilitates the achievement of descriptions of the effectiveness and efficiency of professional development programmes, but also because it helps to identify areas for continuous improvement for their adjustment $[12,27,28]$. Evaluation of in-service teacher professional development systems has often been done on the basis of student performance indicators [5], which should be combined with more qualitative information from key responsible agents and stakeholders. The TEAVET project that is presented in the subsequent section builds upon this framework. 


\subsection{Towards a Sustainable VET System in Albania: The TEAVET Project}

In Albania, the MoESY led the Albanian National Strategy of Pre-University Education (2014-2020) [29] and aimed to provide a solution to the need to improve the competencies of in-service teachers [30]. For that, MoESY asked Albanian universities to contribute to building a high-quality VET system by means of transforming themselves into main providers. In this context, the Erasmus+ project Developing Teacher Competences for a Comprehensive VET System in Albania (TEAVET, 2017-2020) was designed to build this capacity under Key Action 2, Capacity Building in Higher Education, and launched to cooperate in the innovation and exchange of good practices. Relevant information and products of the project are available at https: / / teavet.org (accessed on 3 July 2021).

TEAVET is a structural project since one of the partners is the Ministry of Education of Albania (MoESY). This implies the development of a strategic plan for improvements and reforms that reinforces the systemic impact of the project and strengthens the links between society and institutions. Apart from the Ministry, the other partners are Albanian and European Union universities. On the one hand, the Albanian consortium is composed by the MoESY, as well as by eight universities that represent the main regions of Albania from north to south: The Sports University of Tirana (SUT), the University College "Pavaresia Vlore" (KUPV), the University of Durres (UAMD), the University of Elbasan (UNIEL), the University of Gjirokastra (EÇUG), the University of Korça (UNK), the University of Shkodra (UNISHK) and the University of Vlora (UV). On the other hand, the European Union consortium is composed by the University of Turku (UTU, Finland), the Danube University Krems (DUK, Austria) and the coordinator of the project, the University of León (ULE, Spain). These universities have extensive experience in both training educators and the field of LLL.

The project is structured into different work packages that include specific deliverables. The six work packages listed focus on the development of the project, whereas the other two relate to management and dissemination activities (see Appendix A).

1. Needs analysis on LLL for in-service teachers.

2. Designing of training courses and creation of LLL centres.

3. Training of teacher educators.

4. LLL teacher training system.

5. Evaluation of the LLL teacher training system.

6. Evaluation of the project.

The TEAVET project design and implementation builds on the previous theoretical framework based on five dimensions and key success factors [26]. According to this theoretical framework, the design and implementation phases of the TEAVET project, which integrate previous work packages, are as follows from 2017 to 2020:

1. Defining a strategy for a comprehensive VET system for Albanian in-service teachers. This strategy is based on an in-depth needs analysis of the LLL training needs of inservice teachers. This preparation phase is composed of three main activities: needs analysis reports about universities and educational systems from different views (MoESY, universities, teachers' associations, school representatives, etc.), a seminar on Teacher competences for a comprehensive VET system attended by 80 people and the needs analysis final report focused on the needs for a comprehensive VET system for teacher training. The needs analysis identified several areas to be reinforced: new methodologies for professional development, introduction of Information and Communication Technologies (ICT), updating of curriculum and improving teachers' competences for a more inclusive system. It also recommends that new teachers be supported by experienced teachers in the school and by professional networks and that they get involved in school activities by sharing their expertise in specific areas. These recommendations are in line with the design of the courses implemented in this project. 
2. Establishing new expertise of teacher training in Albanian universities. This objective was achieved through training workshops and training visits to European universities (UTU and DUK) with expertise in VET. The experts provided a full range of capacities and skills to academic staff from Albanian universities to cover all the aspects that are necessary for the effective and efficient development and implementation of training courses as teacher educators.

3. Establishing LLL centres for teacher training in Albanian universities according to the strategy of MoESY and to the needs of in-service teachers.

4. Designing a training programme comprising 16 training courses of 2 credits. In line with the needs analysis, the content of the courses focused on teaching and learning strategies supported by ICT, inclusive education and citizenship and managing conflicts. From March to June 2019, there was a piloting of one training course by each Albanian university $(n=8)$ with participation from 160 in-service teachers.

5. An accreditation system of LLL courses was established by MoESY. This system, which composed of the registration, accreditation and monitoring of VET courses, includes a national information management system and database of teacher training based on an online application system. This application has been settled by MoESY for registered teachers on training courses and to manage the assessment processes, exams, course profile, etc. All 16 courses designed in the previous phase were accredited by MoESY.

6. Implementation of training courses by LLL centres in Albanian universities during the academic year 2019-2020. As such, 14 out of 16 accredited courses were implemented by one or several universities, accruing to a total of 41 courses (see Table 1).

Table 1. TEAVET courses implementation.

\begin{tabular}{cc}
\hline Course Title & Number of Universities per Course \\
\hline Active citizenship in a global society & 2 \\
Inclusive classroom strategies & 4 \\
Foster critical thinking through media analysis & 3 \\
Basic skills for active citizenship & 3 \\
Teaching methodology & 6 \\
Media literacy and online communication & 3 \\
Media literacy in a digitalised world & 3 \\
Digital tools for learning/teaching & 2 \\
Psychology of child development & 3 \\
Clended learning with Learning Management Systems & 4 \\
Communication and conflict management & 1 \\
Project-based teaching and learning & 2 \\
Total & 1 \\
\hline
\end{tabular}

Source: Own elaboration.

Figure 1 illustrates the project phases, based on Deming's continuous improvement cycle (plan, do, check, act) [28], that integrate the five dimensions according to the theoretical framework for VET reform implementation [29]. This cyclical structure of improvement begins with needs analysis and ends with evaluation, which is the aim of this study.

This study is based on the evaluation of the VET system for in-service teachers and on the evaluation of the project. Consequently, the aim of this study is to assess the VET system for in-service teachers in Albania under the theoretical framework based on five dimensions for a successful VET system. Specifically, the research questions are the following: (1) what are the key success factors under the five dimensions (context, content, commitment, capacity and clients) that had more impact on how to implement a successful VET system in Albania? and (2) what are the main elements for the sustainability of the VET system within the Albanian context? 


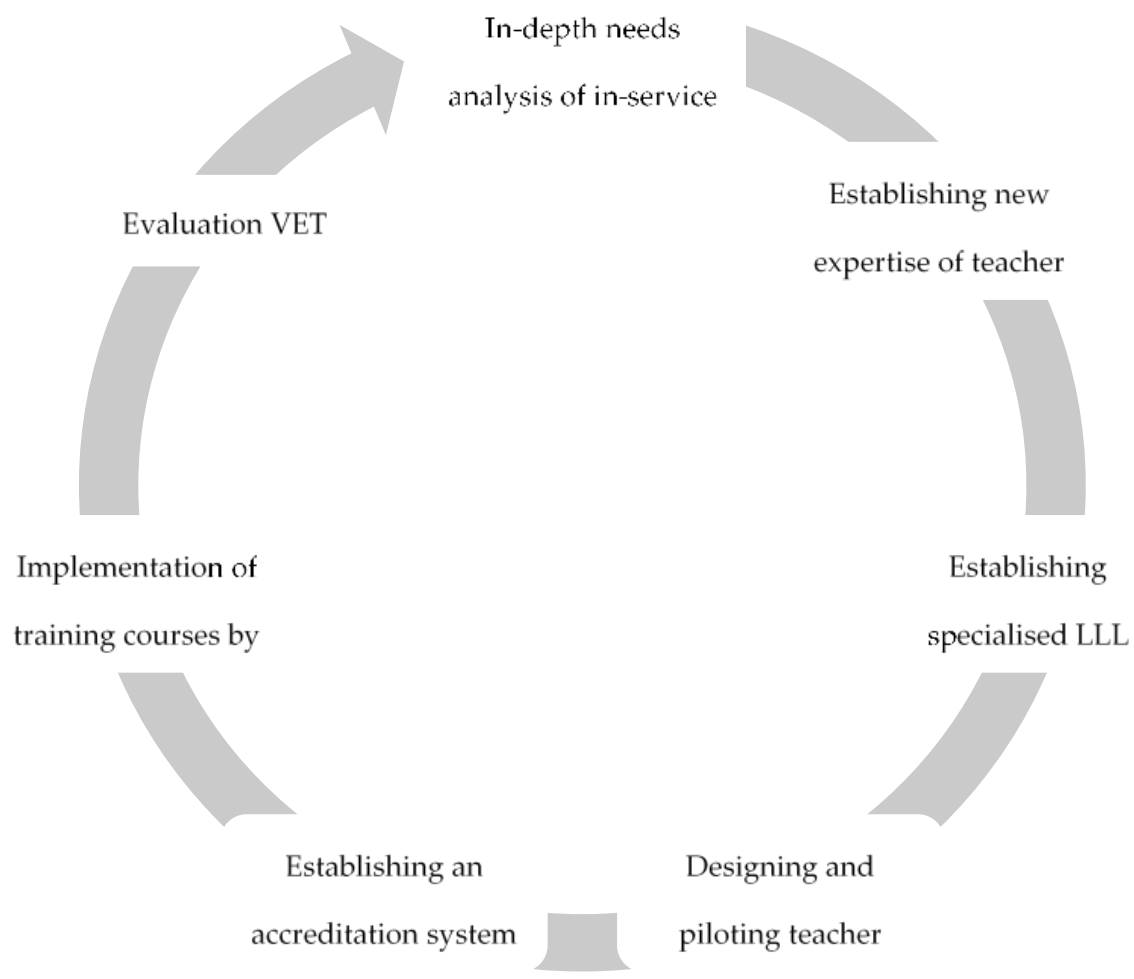

Figure 1. Project phases and VET system dimensions. Source: Own elaboration.

\section{Materials and Methods}

This study is framed within evaluative research or programme evaluation research [31] through a mixed methods design that merges quantitative data (questionnaires) and qualitative information (assessment and reports). Information from questionnaires has been retrieved from in-service teachers and teacher educators from universities, whereas assessment reports correspond to self-assessment reports from the directors of the LLL centres created at eight Albanian universities and MoESY and the impact report prepared by an external expert at the end of the project.

The evaluation followed three phases in terms of target groups and instruments for collecting data:

1. Evaluation by in-service teachers and teacher educators:

Concerning the evaluation by in-service teachers, in May and June 2020 a survey was conducted in order to analyse teacher characteristics, motivations and their level of satisfaction with the courses implemented from September 2019 to May 2020. The research instrument took the form of an on-line questionnaire (Student Course Evaluation Questionnaire, presented in Supplementary Materials). Concerning content validity, this questionnaire was based on course evaluation questionnaires that have been used in previous Erasmus+ projects coordinated by members of the TEAVET consortium (U3MAL: developing third mission activities in Albanian universities; ICTentre: supporting entrepreneurial education in ICT in Vietnamese higher education institutions). Additionally, expert validity was used by asking an expert of each partner institution $(n=12)$ to review the items of the questionnaire. Specifically, the review from MoESY was very relevant to re-phrase the content of some items to be adapted to the Albanian non-higher education context and to prepare the version translated into Albanian. The final version of the questionnaire was agreed by all partner institutions. This version was used in the pilot phase, which took place from March to June 2019, with the participation of 160 in-service teachers, who did not propose any modifications to the questionnaire. The questionnaire was supplied in both English and Albanian and comprises the following sections: 1. background information and 2. degree of satisfaction (1-to-5-point Likert scale) about the 
course attended. There are 36 items organised in 6 dimensions: content and organisation, learning resources and facilities, attendants' participation, teaching methods, trainers and feedback and assessment. Furthermore, the qualitative evaluation was composed of yes/no questions (This was a worthwhile course, would you enroll again?, would you recommend this course to a colleague?) and open questions (regarding the suitability of the time of year of the course, best features and improvement areas). Additionally, 1775 in-service teachers answered the questionnaire (response rate 76\%) investigating the courses implemented by the 8 Albanian partner universities whose respondents are presented in Table 2. Most of them were women (89\%), aged between 36 to 45 years old (79\%), who have worked as teachers in compulsory education for an average of 12.5 years.

Table 2. In-service teacher respondents by university.

\begin{tabular}{cc}
\hline University & $\%$ \\
\hline Sports University of Tirana & 4.3 \\
University “Aleksandër Moisiu” Durres & 25.8 \\
University “Fan S. Noli” & 2.8 \\
University College “Pavarësia Vlorë" & 9.5 \\
University of Elbasan & 4.7 \\
University of Gjirokastra & 16.4 \\
University of Shkodra & 8.7 \\
University of Vlora & 27.8 \\
\hline
\end{tabular}

Source: Own elaboration.

Concerning the evaluation by teacher educators, also in May/June 2020, they completed an on-line questionnaire (Teacher Educators' Course Evaluation Questionnaire, presented in Supplementary Materials). Content validity of this questionnaire followed the same expert validity procedure as the one described for the Student Course Evaluation Questionnaire. This questionnaire was also provided in both English and Albanian and comprises the following sections: 1 . background information; 2 . degree of satisfaction (1-to-5-point Likert scale) about the course/s in question (select course/s) with overall experience, organisational aspects, teaching methods, attendants, location and materials; 3. qualitative evaluation of the course that included yes/no questions (Would you teach again in this course? If not, explain the reasons, would you recommend this course to an in-service teacher? If not, explain the reasons) and open questions about the suitability of the time of year, best features and areas for improvement. Subsequently, 44 out of 54 teacher educators responded to the questionnaire (response rate $81.5 \%$ ). Almost $80 \%$ of them were women, half of them between 36 and 45 years old, and the average number of years spent working at the university was 6.6.

2. Evaluation by MoESY and LLL centres: Academic staff in charge of the LLL centres of the 8 Albanian universities and the MoESY prepared a self-evaluation report that focused on identifying strengths, weaknesses and recommendations for improvements of the VET system.

3. Evaluation by an external expert: An external expert prepared the impact report [32], which was based on documentary analysis of project outcomes and deliverables, as well as on interviews with key informants from the ULE (coordinator), KUPV (co-coordinator), MoESY (partner) and UNK (partner).

Concerning data analysis, quantitative information collected during the surveys (phase 1) was analysed by means of descriptive statistics, factor analysis and correlations using the SPSS Statistics software, version 26.0. Qualitative information collected using open questions in surveys (phase 1) or as reports (phases 2 and 3) was analysed by means of a content analysis assisted by MAXQDA 2020 software. Categorisation focused on the selection of text fragments that express strengths or weaknesses that were allocated to the five dimensions presented in the theoretical framework (context, content, commitment, capacity and clients) or to the 'others' category, when necessary. 


\section{Results and Discussion}

The results on the key success factors that had more impact on how to implement a successful VET system for in-service teachers in Albania and the key elements for its sustainability are presented according to the five dimensions (context, content, commitment, capacity and clients).

\subsection{Context}

As stated in the self-evaluation reports prepared by the directors of the eight LLL centres in Albanian universities and by MoESY and in the impact report prepared by an external expert, context fit is one of the most remarkable strengths of the TEAVET project proposal and its outcomes. As shown in previous literature $[6,18,19]$, context fit policies are necessary to guarantee the sustainability of professional development systems. Some of the facts stated in these reports are the following:

- The project proposal contributes to the Albanian educational policies for the implementation of the Albanian Strategy for Vocational Education Training and Lifelong Learning (2014-2020) in relation to in-service pre-university teacher training, which was launched by MoESY, a partner in the project. The high level of involvement of the Ministry has been pointed out by the directors of the LLL centres and by the external expert as a key element in the sustainability of the VET system.

- The first phase of the project was specifically devoted to identifying the training needs of Albanian in-service teachers and the required key competencies at the European level.

- These competency areas emerged from both original research undertaken by the project (needs analysis), but also from the strategic developmental needs of the Albanian education system.

- However, directors of LLL centres agree about the need for more contextualisation during course implementation with real situations based on professional practice.

\subsection{Content}

The self-evaluation and impact reports each cover several sections related to content, focusing on the characteristics of the reform being implemented, including the overall strategy and the accountability measures used to evaluate it. According to these reports, in the TEAVET project these elements were met as follows:

- $\quad$ As stated in the context dimension, the strategy for a comprehensive VET system was designed according to the national context (Albanian policy framework and in-service teachers' needs), and to European standards. In this sense, as stated in the impact report, "Albania, as a candidate member of the European Union, has consciously sought to bring its systems and structures in line with emerging models of best practice highlighted by the European Commission" [32].

- In the strategy, for the first time universities were placed by MoESY as key agents for the delivery of LLL for in-service teachers as highlighted in previous research [22,23]. As expressed by the external expert [32], "one area of significant impact relates to the Higher Education system, to bring staff and HEIs directly into the provision of VET".

- The training plan had two stakeholders or clients: teacher educators from universities in the first stage and in-service teachers who were trained by teacher educators in the second stage.

- The courses were piloted in terms of training procedures and materials for teacher educators.

- Accountability was a crucial element in the definition of the strategy for the VET system in two ways: (1) the establishment by MoESY of the accreditation system of the LLL Teacher Training System (aims and objectives, accreditation standards, bodies, process) and (2) the establishment by MoESY of a national information management system and database of teacher training to register, assist, monitor and certify the 
assessment process of teachers in training courses. Besides this, the TEAVET project envisaged a transversal quality assurance plan that covered all work packages.

- Considering the content in the implementation phase in which more than 2000 inservice teachers participated, planning strategy, course implementation and evaluation have been very positive in terms of satisfaction and their flexibility in adapting to the COVID-19 lockdowns. However, as stated in the context dimension, self-assessment reports from Albanian universities stress that course content should be more practically oriented.

\subsection{Commitment}

Commitment focuses on political will and cooperation. Derived from previous dimensions, commitment from the Ministry of Education with a clear strategy for in-service teacher training (content) embedded in national needs and international trends (context) has been a key element behind the success of the VET system. In this sense, institutional commitment is essential to guarantee the quality and sustainability of teaching improvement systems [1,7]. Additionally, placing Albanian universities as the main providers of teacher development programmes has had an impact on the level of cooperation between the Albanian higher education system and MoESY. Self-assessment reports and the external expert report highlighted both political will and cooperation beyond the project proposal:

- The consortium has established good cooperation among all partners (EU universities, Albanian universities and MoESY). The active involvement of the MoESY in the management and the implementation of the project has been crucial for the achievement of the project's objectives.

- Cooperation has been formalised with the establishment of the Albanian Network of Lifelong Learning Centres for Teacher Training (NCTT). The success of collaboration led, in the final year of the project, to an additional step (not envisaged in the project proposal); this was the creation of the Assembly for the Training of Lifelong Learning Centres network, which elected a coordinating committee that continues to meet and work on additional training in coordination with MoESY. This networking has been stressed as a key element for future sustainability.

- However, two weak points have been expressed by teacher educators in relation to the institutional commitment which, in their opinion, are crucial for the success and sustainability of universities as LLL providers: improving rewards and institutional conditions in their universities and reinforcing the cooperation within the network of the LLL centres to be more efficient.

\subsection{Capacity}

Following the theoretical framework, capacity refers to personnel, finances, research, time and leadership. All these elements for a successful VET system were met in this project. On the one hand, three of these elements (finance, time and leadership) are related to the specific nature of the TEAVET project and its consortium; this has been granted as a structural project within a specific time frame and budget to build capacity in the field of higher education. Additionally, the leadership executed by the two coordinating institutions (from the EU and Albania), together with MoESY, builds on their level of expertise and on their previous cooperation in another Erasmus+ project (U3M-AL) [23].

On the other hand, personnel and research were specifically emphasised in the analysed reports for the following reasons:

- Academic staff from Albanian universities have learnt from EU practices (learning visits to Austria and Finland and a seminar for the training of teacher educators) concerning how to create an LLL structure and how to design and implement courses. Also, "MoESY actively shared information with them, information that may not have been available to HEI staff and institutions otherwise". 
- Additionally, EU partners helped Albanian academic staff to focus on the area of academic and research output (needs analysis, satisfaction surveys, etc.), as shown in their participation at the final TEAVET conference in November 2020.

- There is an ongoing process of capacity building through formally integrating the LLL centres into university structures, and thus reinforcing the third mission of the higher education sector in Albania as an LLL provider [21], and in the MoESY training database, as part of the accreditation system. In the opinion of the external expert, "it's an indicator towards sustainability that indicates the awareness of the need to move beyond an ad-hoc structure to one that is more permanent".

Concerning weaknesses for sustainability, it has been reported that there is still a certain lack of concreteness on the financial maintenance of the LLL centres and their staff after the financial support of the TEAVET project. As is often the case with external funding that supports structural measures, the end of the financial support is one of the main risks for an innovation activity in the field of education to continue [33]. In this case, financial sustainability will be provided partly by small fees paid by in-service teachers, as established by MoESY, and partly by universities' own incomes, which will be defined for LLL centres in the budget for each academic year. Within this institutional commitment, the VET system strategy must define incentives for academics, whether they are in the form of financial or non-financial compensation, to participate as teacher educators.

\subsection{Clients}

Clients cover a broad range of stakeholders that are ultimately affected by the implementation of the VET system (employers, intermediaries, educators, etc.). In this project, the clients are, primarily, in-service teachers and teacher educators. Due to the timeline of the project, there is not yet information available on how the training has impacted the professional performance of in-service teachers based on the opinion of school principals or students.

\subsubsection{In-Service Teachers' Satisfaction}

A survey was carried out to describe the level of satisfaction of in-service teachers with the courses taken. To test the empirical validity of the structure of the items in the questionnaire, a factor analysis of principal components was developed. The principal components method with varimax rotation was used. The goodness-of-fit measures for the model were appropriate: Bartlett's test of the sphericity significance $<0.000$ and KMO value $=0.960$. The resulting factorial structure identified four factors that account for $71.1 \%$ of the variance (see Table 3). In factor 1, items of three theoretical dimensions saturate: course content and organisation; learning resources and facilities; and, to a lesser extent, attendants' participation. Factor 2 is based on the content of the items grouped in the teaching methods dimension. Factor 3 includes the items of the theoretical dimension feedback and assessment. Finally, the items included in the dimension trainer saturate in factor 4 .

Given the results of the factor analysis, the initial theoretical structure was maintained for subsequent analyses. Table 4 shows the descriptives (mean and standard deviation) and Cronbach's $\alpha$ value of each dimension. The degree of satisfaction expressed by the in-service teachers is very high. The dimensions that reveal greater satisfaction are: trainer (mean $=4.87, \mathrm{SD}=0.50)$, course content and organisation (mean $=4.85, \mathrm{SD}=0.42$ ) and teaching methods (mean $=4.83, \mathrm{SD}=0.48$ ). The lowest score is observed in the attendants' participation dimension (mean $=4.71, \mathrm{SD}=0.61$ ). The value, however, is high too.

Cronbach's $\alpha$ was used to describe the internal consistency of each dimension. All dimensions showed strong internal consistency values. Cronbach's $\alpha$ values for five of them were higher than 0.9 .

Finally, the correlations between each dimension were calculated. Table 5 shows the values of the Pearson correlation coefficients between the dimensions and their associated $p$-values. All correlations are statistically significant $(p<0.01)$. Feedback and assessment 
is the dimension showing the strongest correlations. Of note are the correlations of this dimension with the following: teaching methods ( $\mathrm{r}$-Pearson coefficient $=0.744$ ), trainer $(\mathrm{r}$-Pearson coefficient $=0.722)$ and learning resources and facilities $(\mathrm{r}$-Pearson coefficient $=$ 0.702). The table also shows a high correlation between the dimensions: teaching methods and trainer $(\mathrm{r}$-Pearson coefficient $=0.751)$.

Table 3. Matrix principal components with varimax rotation of in-service teachers questionnaire.

\begin{tabular}{|c|c|c|c|c|}
\hline- & \multicolumn{4}{|c|}{ Component } \\
\hline Questionnaire items & 1 & 2 & 3 & 4 \\
\hline The course learning outcomes were clear & 0.780 & 0.225 & 0.239 & 0.194 \\
\hline The course syllabus (content) was explained at the beginning of the course & 0.770 & 0.218 & 0.148 & 0.195 \\
\hline The course was delivered as outlined in the syllabus & 0.780 & 0.246 & 0.112 & 0.215 \\
\hline The course was well organised (e.g., timely access to materials, notification of changes, etc.) & 0.778 & 0.246 & 0.130 & 0.255 \\
\hline The amount of workload/homework was manageable & 0.707 & 0.304 & 0.164 & 0.121 \\
\hline Classrooms were satisfactory (space, light, ventilation, etc.) & 0.597 & 0.138 & 0.383 & 0.135 \\
\hline Equipment for learning was appropriate (computers, internet, etc.) & 0.573 & 0.214 & 0.387 & 0.110 \\
\hline Learning documents were useful (lesson plans, course notes, ppt, etc.) & 0.572 & 0.257 & 0.436 & 0.144 \\
\hline I participated actively in the course & 0.210 & 0.480 & 0.408 & 0.078 \\
\hline Attendants participated actively in the course & 0.276 & 0.470 & 0.427 & 0.125 \\
\hline Contents were presented clearly & 0.229 & 0.682 & 0.126 & 0.395 \\
\hline The pace of the course was appropriate & 0.301 & 0.713 & 0.180 & 0.254 \\
\hline The course stimulated my interest on the subject area & 0.209 & 0.775 & 0.195 & 0.197 \\
\hline The course is useful for applying learning outcomes in my current work as teacher & 0.253 & 0.770 & 0.250 & 0.187 \\
\hline The practical activities were appropriate & 0.280 & 0.703 & 0.292 & 0.200 \\
\hline Teaching methods encouraged participation & 0.262 & 0.734 & 0.256 & 0.260 \\
\hline The trainer(s) demonstrated in-depth knowledge of the subject & 0.219 & 0.250 & 0.233 & 0.832 \\
\hline The trainer(s) encouraged discussions & 0.216 & 0.268 & 0.198 & 0.803 \\
\hline The trainer(s) responded to questions & 0.231 & 0.247 & 0.241 & 0.830 \\
\hline The trainer(s) gave guidance on where to find resources & 0.237 & 0.260 & 0.251 & 0.774 \\
\hline Information about assessment was communicated clearly & 0.274 & 0.210 & 0.733 & 0.307 \\
\hline Feedback showed how to improve my work (e.g., corrections and comments) & 0.202 & 0.291 & 0.759 & 0.227 \\
\hline Feedback on assessment was timely & 0.249 & 0.237 & 0.767 & 0.234 \\
\hline The methods of assessment related to the course learning outcomes & 0.248 & 0.316 & 0.733 & 0.252 \\
\hline
\end{tabular}

Source: Own elaboration.

Table 4. Descriptive statistics for each dimension.

\begin{tabular}{cccc}
\hline Dimension & Mean & SD & Cronbach's $\alpha$ \\
\hline D1-Course content and organisation & 4.85 & 0.42 & 0.908 \\
D2-Learning resources and facilities & 4.81 & 0.52 & 0.895 \\
D3-Attendants' participation & 4.71 & 0.61 & 0.852 \\
D4-Teaching methods & 4.83 & 0.48 & 0.948 \\
D5-Trainer & 4.87 & 0.50 & 0.955 \\
D6-Feedback and assessment & 4.82 & 0.52 & 0.939 \\
\hline
\end{tabular}

Source: Own elaboration.

Table 5. Correlations matrix and $p$-values.

\begin{tabular}{ccccccc}
\hline Dimensions & D1 & D2 & D3 & D4 & D5 & D6 \\
\hline D1-Course content and organisation & 1 & $0.652 *$ & $0.476^{*}$ & $0.603^{*}$ & $0.522^{*}$ & $0.580^{*}$ \\
D2-Learning resources and facilities & - & 1 & $0.599 *$ & $0.670^{*}$ & $0.636^{*}$ & $0.702^{*}$ \\
D3-Attendants' participation & - & - & 1 & $0.671^{*}$ & $0.589^{*}$ & $0.650^{*}$ \\
D4-Teaching methods & - & - & - & 1 & $0.751^{*}$ & $0.744^{*}$ \\
D5-Trainer & - & - & - & - & 1 & $0.722 *$ \\
D6-Feedback and assessment & - & - & - & - & - & 1 \\
\hline
\end{tabular}


Nearly all in-service teachers (99\%) were of the opinion that the course had been worthwhile, 97\% indicated that they would attend again, and almost all participants (99.5\%) stated that they would recommend it to other in-service teachers. In the open questions, participants considered the course's flexibility to be a strength, particularly during the implementation phase when required to adapt to the COVID-19 lockdowns at the end of the 2019-2020 academic year. As a weak point, they commented on the need to share experiences and cooperate with schools so courses can be more oriented to real situations in the school context.

\subsubsection{Teacher Educators' Satisfaction}

The degree of satisfaction shown by 44 teacher educators who answered the questionnaire [34] is also very high (see Figure 2). The whole experience and the methodology were the most valued, with more than $80 \%$ of participants being very satisfied. Next, with satisfaction percentages above $70 \%$, were items related to the organisation of the course, its content, the academic materials used, the practical training and the classrooms. Finally, some items related to the performance of the participants and their participation received lower ratings.

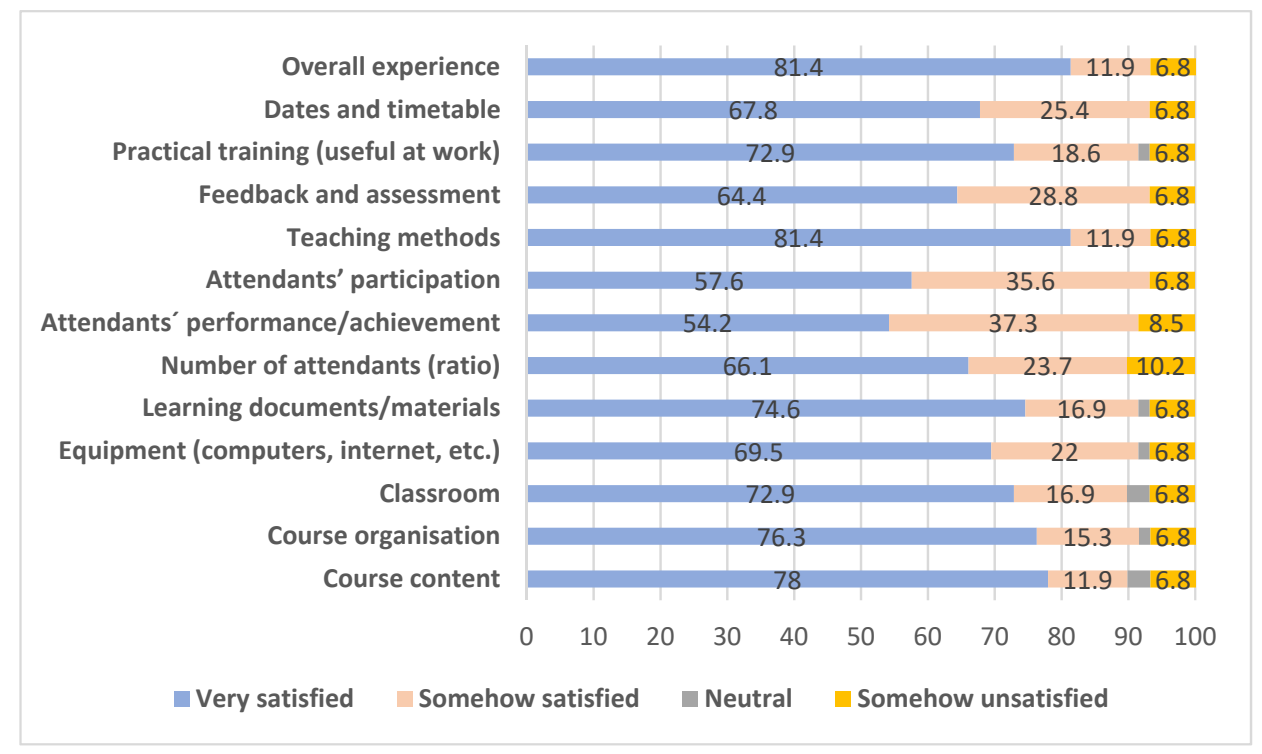

Figure 2. Teacher educators' satisfaction (\%). Source: Own elaboration.

Concerning general aspects of the course delivered, $100 \%$ of those surveyed would teach it in the future and would suggest it to a teacher. They considered that the time period was adequate to deliver the course. In the open questions, they commented on the capability created in LLL centres within universities through the involvement of their academic staff as teacher educators. However, two weak points were expressed by teacher educators which, in their opinion, are crucial for the sustainability of universities as LLL providers: improve rewards and institutional conditions in their universities and reinforce the networking of the 8 LLL centres to be more efficient.

\section{Conclusions}

This study on the assessment of the Albanian VET system for in-service teachers, created with the financial support and expertise of the TEAVET project consortium, answers two research questions: (1) what are the key success factors under five dimensions (context, content, commitment, capacity and clients) that had more impact on how to implement a successful VET system in Albania? and (2) what are the main elements for the sustainability of the VET system within the Albanian context? Conclusions to these research questions contribute to provide both theoretical and practical implications on how to implement successful VET systems. 
On the one hand, identified key success factors empirically support previous literature on how to implement successful VET systems grouped in five dimensions [26]. Hence, concerning theoretical implications, it confirms the suitability of this theoretical framework and highlights the high level of interdependence between the five dimensions. Specifically, in this study, key success factors for a VET system in each dimension are the following:

- Context fit has been considered from a bottom-up approach (local-national-European): training needs of the target group (in-service pre-university teachers), Albanian LLL policy and European standards have been considered at all stages of the project.

- Content: All elements of the reform plan have been specifically designed and agreed with stakeholders, from the overall strategy based on including universities as LLL providers, to the design and implementation of the reform and the accountability and accreditation measures to evaluate it.

- Commitment: Institutional commitment has proved to be essential to guarantee the quality and sustainability of the VET system. In this sense, the involvement of the Albanian MoESY, which has encouraged networking between LLL centres in Albanian universities, has been a key success factor.

- Capacity has undertaken all key factors, that is, personnel, finances, research, time and leadership, within the lifecycle and financial support of the TEAVET project. Additionally, the expertise of EU partners has contributed to increasing the training and research competences of academic staff at Albanian universities.

- Clients: In-service teachers and teacher educators are highly satisfied with the VET system, specifically in the implementation phase.

On the other hand, the confirmation of these five interrelated dimensions for a successful VET system is very relevant at a practical level for their implications on sustainability. In this study, the main elements for the sustainability of the VET system within the Albanian context, that is, its capacity to continue after TEAVET project financial and advisory support, lead to practical implications in the top-down educational policy that have consequences for in-service teachers as beneficiaries of the VET system in a bottom level. In this study, the main elements that have been pointed out by MoESY and Albanian universities as essential to guarantee sustainability are:

- $\quad$ The VET strategy is based on context fit and accountability: The VET system builds on the Albanian LLL policy and addresses Albanian country-specific priorities based on the identification of the target group's needs. Furthermore, the quality of the system has been controlled through accreditation systems.

- Commitment and networking, both by MoESY, as the VET system is part of its policy strategy and, as is particularly relevant, by the LLL centres, which have upgraded their networking through the creation of the Assembly for the Training of Lifelong Learning Centres network.

- Capacity by reinforcing the third mission of the higher education sector in Albania as an LLL provider and envisaging a self-sustainable financial mechanism based on small fees and universities' budget for LLL.

- All stakeholders involved, from MoESY to universities and schools, have had the ability to address real needs building and respect their institutional management frameworks.

In spite of these strengths for sustainability in the top-down policy strategy of the VET system, there are certain threats to its future development, as identified at the bottom level, that need to be addressed within the Albanian VET policy strategy:

- Monitoring and close cooperation with schools, so that training is contextualised to concrete in-service teachers' needs on a daily basis.

- Recognition and rewards for those academics and in-service teachers committed to LLL.

Overall, the TEAVET project has contributed to sustainable development in education [1] through the creation of a VET system in Albania to improve the quality of in-service 
teachers' training embedded in their educational policy strategy that addresses key elements for feasible future development. This study has contributed to providing valuable theoretical and practical information for the evaluation of a VET system for in-service teachers in its early stage. However, as a limitation of this study, for a comprehensive assessment of the impact of the implementation of the VET system for in-service teachers on schools and students' learning, a follow-up study within 2 to 3 years would be needed. In this sense, further research about the effect of teaching innovation on learning is needed.

Supplementary Materials: The following are available online at https:/ /www.mdpi.com/article/10 .3390/su13168739/s1, TEAVET Student Course Evaluation Questionnaire, TEAVET Teacher Educators' Course Evaluation Questionnaire.

Author Contributions: Conceptualisation, A.R.-E. and C.F.; methodology, M.-J.V. and J.V.; writingoriginal draft preparation, A.R.-E., C.F. and M.-J.V.; writing—review and editing, A.R.-E., C.F., M.-J.V. and J.V.; supervision, M.J.V. and J.V.; project administration, J.V., M.-J.V. and C.F.; funding acquisition, J.V. All authors have read and agreed to the published version of the manuscript.

Funding: This research was co-funded by the Erasmus+ Programme of the European Union, grant number 586300-EPP-1-2017-1-ES-EPPKA2-CBHE-SP.

Institutional Review Board Statement: Not applicable.

Informed Consent Statement: Not applicable.

Data Availability Statement: Reports supporting the results can be found on the TEAVET project website: https: / / teavet.org (accessed on 30 June 2021). The datasets generated during surveys are available from the corresponding authors on reasonable request.

Conflicts of Interest: The authors declare no conflict of interest. The funders had no role in the design of the study; in the collection, analyses or interpretation of data; in the writing of the manuscript; or in the decision to publish the results.

\section{Appendix A}

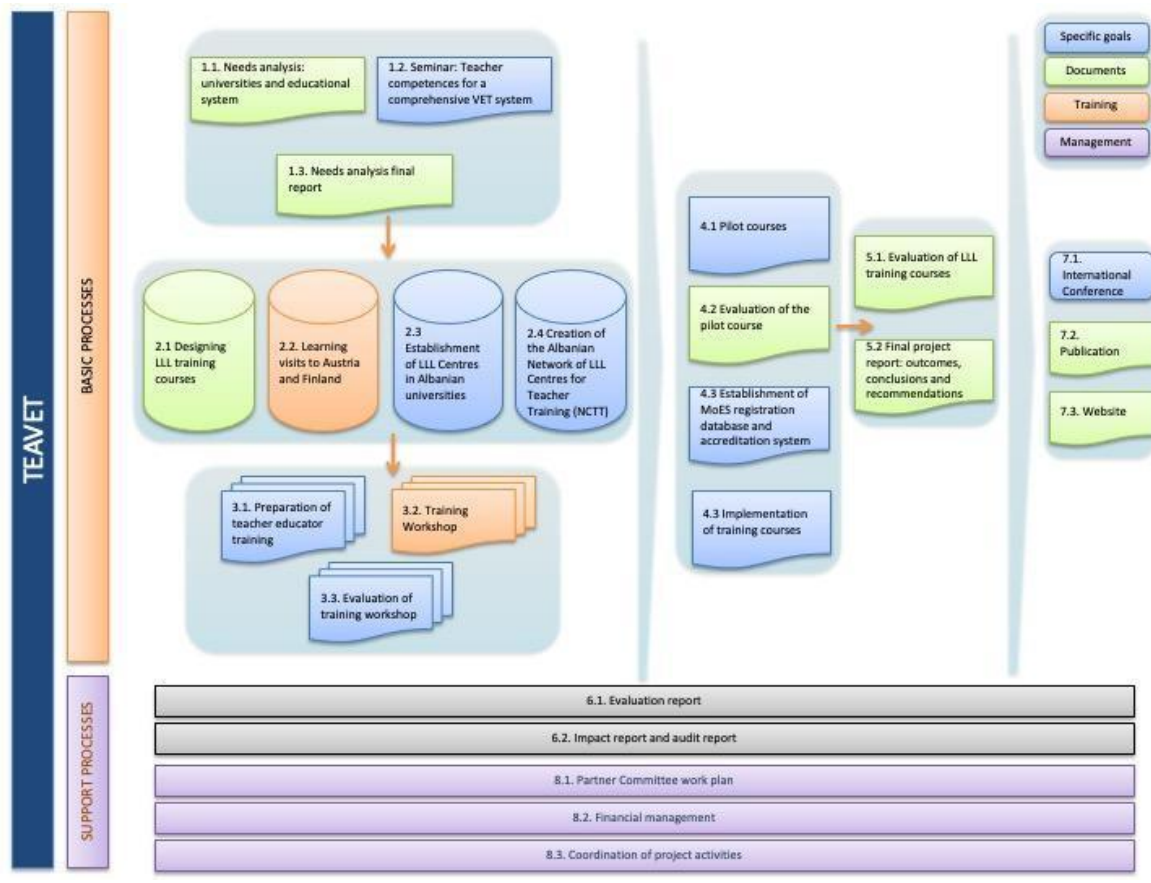

Figure A1. TEAVET project structure. Source: Own elaboration. 


\section{References}

1. United Nations. Transforming Our World: The 2030 Agenda for Sustainable Development. Resolution Adopted by the General Assembly on 25 September 2015. Available online: https://sustainabledevelopment.un.org/post2015/transformingourworld/ publication (accessed on 23 March 2021).

2. European Commission. COM(2016)381 Final Communication from the Commission to the European Parliament, the Council, the European Economic and Social Committee and the Committee of the Regions. A New Skills Agenda for Europe: Working Together to Strengthen Human Capital, Employability and Competitiveness; European Commission: Brussels, Belgium, 2016.

3. European Commission. COM(2016)941 Final Communication from the Commission to the European Parliament, the Council, the European Economic and Social Committee and the Committee of the Regions: Improving and Modernising Education; European Commission: Brussels, Belgium, 2016.

4. Balbay, S.; Pamuk, G.; Temir, T.; Doğan, C. Issues in pre-service and in-service teacher training programs for university English instructors in Turkey. J. Lang. Linguist. Stud. 2018, 14, 48-60.

5. Roca-Campos, E.; Renta-Davids, A.I.; Marhuenda-Fluixá, F.; Flecha, R. Educational Impact Evaluation of Professional Development of In-Service Teachers: The Case of the Dialogic Pedagogical Gatherings at Valencia "On Giants' Shoulders". Sustainability 2021, 13, 4275. [CrossRef]

6. European Commission. COM(2012)669 Final Communication from the Commission to the European Parliament, the Council, the European Economic and Social Committee and the Committee of the Regions. Rethinking Education: INVESTING in Skills for Better Socio-Economic Outcomes; European Commission: Strasbourg, France, 2012.

7. UNESCO. ED/2012/PI/H/1 UNESCO Strategy on Teachers (2012-2015); UNESCO, 2012. Available online: https:/ / unesdoc.unesco. org/ark:/48223/pf0000217775 (accessed on 26 February 2021).

8. European Union. COM(2007)392 Final Improving the Quality of the Education and Training of Teachers; European Union: Brussels, Belgium, 2016.

9. European Commission. COM(2017)248 Final Communication from the Commission to the European Parliament, the Council, the European Economic and Social Committee and the Committee of the Regions. School Development and Excellent Teaching for a Great Start in Life; European Commission: Brussels, Belgium, 2017.

10. European Union. Communication 2017/C 62/02 Conclusions of the Council and of the Representatives of the Governments of the Member States, Meeting within the Council, on Inclusion in Diversity to Achieve a High Quality Education For All; European Union: Brussels, Belgium, 2017.

11. European Commission. COM(2020)274 Final Communication from the Commission to the European Parliament, the Council, the European Economic and Social Committee and the Committee of the Regions. European Skills Agenda for Sustainable Competitiveness, Social Fairness and Resilience; European Commission: Brussels, Belgium, 2020.

12. Lucas, R.I.; Promentilla, M.A.; Ubando, A.; Girard Tan, R.; Aviso, K.; Danielle Yu, K. An AHP-based evaluation method for teacher training workshop on information and communication technology. Eval. Program Plan. 2017, 63, 93-100. [CrossRef] [PubMed]

13. Darling-Hammond, L. Teacher education around the world: What can we learn from international practice? Eur. J. Teach. Educ. 2017, 40, 291-309. [CrossRef]

14. Taranto, D.; Buchanan, M.T. Sustaining Lifelong Learning: A Self-Regulated Learning (SRL) Approach. Discourse Commun. Sustain. Educ. 2020, 11, 5-15. [CrossRef]

15. Ilgaz, G.; Eskici, M. Examination of Teacher Candidates' Lifelong Learning Competence and Basic Motivation Resources as Parts of Sustainability. Sustainability 2019, 11, 23. [CrossRef]

16. Gavín-Chocano, Ó.; Molero, D.; García-Martínez, I. Early Education Care from Its Practitioners to Achieve Sustainability. Sustainability 2021, 13, 3396. [CrossRef]

17. European Commission. SWD(2012)374 Final Supporting the Teaching Professions for Better Learning Outcomes; European Commission: Strasbourg, France, 2012.

18. Murray, J. Teacher Educators' Induction into Higher Education: Work-Based Learning in the Micro Communities of Teacher Education. Eur. J. Teach. Educ. 2008, 31, 117-133. [CrossRef]

19. Murray, J.; Swennen, A.; Shagrir, L. Understanding Teacher Educators' Work and Identities. In Becoming a Teacher Educator: Theory and Practice for Teacher Educators, 1st ed.; Swennen, A., van der Klink, M., Eds.; Springer: Berlin/Heidelberg, Germany, 2009; pp. 29-43.

20. González-Moreira, A.; Ferreira, C.; Vidal, J. Comparative Analysis of the Transition from Early Childhood Education to Primary Education: Factors Affecting Continuity Between Stages. Eur. J. Educ. Res. 2021, 10, 441-454. [CrossRef]

21. European University Association. The Memorandum on Lifelong Learning (a Staff Paper of the European Commission); Results of the European University Association (EUA) Consultation; Geneva Office: Geneva, Switzerland, 2001.

22. Cendon, E. Lifelong Learning at Universities: Future Perspectives for Teaching and Learning. J. New Approaches Educ. Res. 2018, 7, 81-87. [CrossRef]

23. Mora, J.G.; Ferreira, C.; Vidal, J.; Vieira, M.J. Higher education in Albania: Developing third mission activities. Tert. Educ. Manag. 2015, 21, 29-40. [CrossRef]

24. Mora, J.G.; Serra, M.A.; Vieira, M.J. Social Engagement in Latin American Universities. High. Educ. Policy 2018, 31, 513-534. [CrossRef] 
25. Najam, A. Learning from the Literature on Policy Implementation: A Synthesis Perspective. In IIASA Working Papers, WP-95-061; International Institute for Applied Systems Analysis: Laxenburg, Austria, 2015.

26. Marie Caves, K.; Baumann, S.; Renold, U. Getting there from here: A literature review on vocational education and training reform implementation. J. Vocat. Educ. Train. 2019, 73, 95-126. [CrossRef]

27. Hidayat, D. Approaches to Evaluation: In Pursuit of Appropriacy For EFL Pre-Service Teacher Training Programs in Indonesia. Int. J. Educ. Curric. Appl. 2018, 1, 51-58. [CrossRef]

28. Alauddin, N.; Yamada, S. Overview of Deming Criteria for Total Quality Management Conceptual Framework Design in Education Services. J. Eng. Sci. Res. 2019, 3, 12-20. [CrossRef]

29. Ministry of Education and Sports (MES). Strategy on Pre-University Education Development 2014-2020. Tirana, 2014. Available online: https:/ / planipolis.iiep.unesco.org/sites /default/files/ressources/albania_strategy_on_pre-university_education_dev. pdf (accessed on 11 February 2021).

30. UNESCO. Albania. Education Policy Review: Issues and Recommendations. Extended Report. Section of Education Policy, 2017. Available online: https:/ / unesdoc.unesco.org/ark:/48223/pf0000259245 (accessed on 2 March 2021).

31. Vedung, E. Public Policy and Program Evaluation, 1st ed.; Routledge: New York, NY, USA, 2017.

32. O'Hara, J. Impact Report. Teavet Project. 2021. Available online: https://teavet.org/wp-content/uploads/2021/02/D.6.2Impact-Report.pdf (accessed on 12 March 2021).

33. Grove, M.; Pugh, S. Defining 'sustainability indicators' for higher education teaching and learning innovations. Educ. Pract. 2017, 3, 13-18.

34. Vieira, M.J.; Rodríguez-Esteban, A. Evaluation of LLL Training Courses for in-Service Teachers in Albania. In Proceedings of the TEAVET Project Final Conference, Vlore, Albania, 10-11 November 2020; Cipi, E., Meminaj, M., Eds.; Servicio de Publicaciones. University of León: León, Spain, 2021. Available online: https://teavet.org/wp-content/uploads/2021/05/WP7 -Final-Conference-proceeding-book.pdf (accessed on 5 April 2021). 